\title{
Innovation of Enterprise Economic Management Based on Knowledge Economy
}

\author{
Jingchao Pan \\ Faculty of Economics, Belarusian State University, Minsk, 220030, the Repubilc of Belarus
}

\begin{abstract}
The development of economic globalization has put forward new requirements for the economic management of enterprises in China, and in order to occupy an advantage in the fierce international competition, enterprises must innovate enterprise economic management and establish their unique core competitiveness. To this end, this paper focuses on the two aspects of enterprise economic management and enterprise economic management innovation to study and explore.
\end{abstract}

Keywords: Knowledge-based economy, Economic management, Innovation.

\section{Introduction}

The current background of economic globalization requires enterprises to innovate their economic management concepts and models in order to improve their competitiveness. To this end, enterprises need to establish the concept of sustainable development, adhere to the concept of people-oriented, and improve the effectiveness of their economic management. Enterprise economic innovation is an important manifestation of an enterprise's innovative ability and an important part of its core competitiveness. Therefore, the research of enterprise economic management innovation based on knowledge economy is of great significance to promote the development of enterprises.

\section{The Significance of Enterprise Economic Management}

Enterprises are designed to make economic profits, while strengthening the economic management of enterprises is designed to improve their competitiveness and help them to seek more benefits. Economic management strengthens the motivation of employees and the cohesion between teams, thus bringing into play the power of the group to enhance the competitiveness of the enterprise. Economic management is a mode of management by the management of the enterprise, the ultimate goal of which is to achieve better development of the enterprise. There are different milestones in the process of enterprise economic management, including further clarifying the future direction of the enterprise, motivating employees to work and creating more value for the enterprise. Enterprise economic management is an important component of enterprise management. Through enterprise economic management, we can enhance the flexibility of the enterprise's response to the market, establish a perfect and standardized enterprise operation system, and thus improve the competitiveness of the enterprise.

\section{The Problems of Current Enterprise Economic Management}

With the reform and opening up, China's enterprises are also constantly exploring enterprise economic management, with the promotion of economic globalization, the market has put forward new requirements for China's enterprise economic management, many enterprise economic management concepts and methods are out of line with the requirements of the times, making it impossible to play the advantages of enterprise economic management, this paper briefly introduces the current problems of enterprise economic management.

\subsection{Enterprise Economic Management Concept is Backward}

At present, many managers of enterprises in China have a weak economic management concept, managers focus on innovation management and cost management in the management process, in the management process only focus on how to reduce the cost of enterprises, want to enhance the competitiveness of enterprises through price advantage, this management concept is very backward. In the production and operation process, the management personnel do not pay enough attention to enterprise economic management, which makes the construction of enterprise economic management department backward and lack of professional talents to engage in enterprise economic management. And many economic management personnel's management concept is also out of step with the times, in the management process still adhere to the old management concept, resulting in the management of the focus is not clear, the management of the relevant responsibilities are not specific to individuals, and thus many enterprises' economic management system and economic management departments are equivalent to the virtual, not to play a role in enhancing the competitiveness of enterprises [1].

\subsection{The Construction of Enterprise Economic} Management System is not in Place

There are many problems in the construction of the current enterprise economic management system, which seriously restricts the sustainable development of enterprises. After understanding that most of the current enterprise economic management system is not perfect, so that the management department of the enterprise is like a virtual, many management tasks can not be completed in accordance with the quality and quantity, the management of the enterprise is 
mostly a formality. The management class does not pay enough attention to the management, resulting in the lack of attention to the economic management of the whole enterprise, and the management department personnel are not aware of the significance of their work for the enterprise. The current economic management system is not in place mainly in the following aspects: First, the enterprise has established an enterprise economic management system and enterprise economic management department, but there is no clear management process and management responsibilities, each department is not aware of the significance of economic management for the enterprise, which makes the lack of effective supervision between the various departments, making the economic management system as if it is empty, no one to implement, no one to supervise. Secondly, the economic management system of enterprises is backward, and the economic management system built by them cannot meet the needs of the current development of enterprises, and is also out of line with the requirements of society. Thirdly, the enterprise has established a relatively perfect economic management system, but lacks an effective supervision mechanism, which makes the economic management work not carried out under effective supervision, resulting in the waste of enterprise resources.

\subsection{Enterprise Economic Management in Human Resources Management Work Awareness is Weak}

The current competition between enterprises is ultimately the competition of human resources, human resources become a decisive factor in determining the future development of enterprises. In the survey and understanding, many enterprises are short-sighted in economic management, only limited to the immediate interests, focusing on the enterprise's production cost management and safety management, the awareness of human resources management is very weak, in the process of enterprise economic management is mainly manifested in the following aspects: First, human resources management does not pay attention to the assessment of staff performance, no corresponding assessment and evaluation mechanism and reward and punishment mechanism, making staff The second is that no attention is paid to the skills and experience training of employees, resulting in the skills and experience of employees failing to meet the current market and social needs, which in turn makes the production of enterprises derail from the whole market and the centripetal force of employees towards enterprises is not strong, which in turn restricts the further development of enterprises [2].

\section{The Innovative Measures of Enterprise Economic Management based on Knowledge Economy}

With the reform and opening up, China's enterprises are also constantly exploring enterprise economic management. With the promotion of economic globalization, the market has put forward new requirements for China's enterprise economic management, requiring enterprises to innovate economic management concepts and management methods.

\subsection{Innovative Economic Management Concept}

The innovation of enterprise economic management should first start from the concept, so the managers should first innovate the concept of economic management and guide the enterprise economic management with the latest concept. First of all, managers should realize the importance of economic management for enterprises, constantly strengthen the learning of management concepts and methods, adhere to the management concept and management methods to keep abreast of the times, regularly promote the importance of economic management to employees, and form an atmosphere that attaches importance to economic management in the whole enterprise. Secondly, economic globalization has made strategic management and crisis management the focus of enterprise economic management. In the management process, to ensure the sustainability of the enterprise strategy, managers are required to base on the reality of the enterprise and look to the future, to ensure the comprehensiveness and advancement of the strategy, so as to improve the competitiveness of the enterprise. Finally, enterprises should also innovate the implementation of economic management and improve their ability to respond to crises, so as to improve their competitiveness in the market [3].

\subsection{Improving the Economic Management System}

The management system is the relevant regulations and rules system formulated by the managers to restrain the employees of the enterprise. Economic management system innovation is the basic link of enterprise economic management innovation, so the managers should first innovate the economic management system to make the economic management system meet the current development needs. Enterprise economic management system innovation should be carried out from the following aspects: First, in the development of enterprise economic management system should be combined with the enterprise's own reality, so that the system construction can meet the needs of enterprise development, the responsibility of employees to carry out a clear division and positioning, so as to enhance the enthusiasm and initiative of staff work; Second, economic management system innovation should be done from the perfect supervision system, effective internal oversight can improve the effectiveness of economic management work, for this reason, we should combine the actual situation of the enterprise to establish a supervision system in line with the enterprise, strengthen the supervision of the enterprise staff and the supervision of the enterprise economic management department, so as to ensure that the economic management department personnel in the management process can efficiently carry out management work, which is conducive to the integration of the enterprise construction and improve the competitiveness of the enterprise in the market.

\subsection{Strengthen the Innovation of Human Resources Management}

The advent of knowledge economy makes human resources 
become the core resources of enterprises, and talents become the core competitiveness of enterprises. First of all, we should innovate the management concept, establish and adhere to the "people-oriented" management concept, start from the needs of employees, strengthen staff training, improve the knowledge reserve of employees, so as to improve the centripetal force of employees to the enterprise. Secondly, we should adopt diversified means to explore talents and cultivate them, and consider them from their moral, intellectual, physical, social and aesthetic aspects when recruiting them. When recruiting, enterprises should base on the future development plan of the enterprise to create a high-quality talent team to drive the future development of the enterprise. At the same time, in order to improve the enthusiasm and solidarity of the enterprise's employees, the enterprise can regularly organize team building to strengthen the cohesion of the enterprise's employees[4].

\section{Conclusion}

Under the background of knowledge economy, enterprise economic management innovation helps enterprises to keep pace with the times, follow the social trend and enhance the competitiveness of enterprises. For this reason, enterprises should innovate the concept of economic management, strengthen the construction of economic management system and strengthen enterprise human resources management, managers should be based on the actual enterprise and look at the future of the enterprise, through enterprise economic management to enhance the competitiveness of enterprises in the market.

\section{References}

[1] Dong Koon. Innovation and practice of enterprise economic management based on knowledge economy. China Business On, 2018(2).

[2] Meng Lihui. Research on innovation of economic management of tea enterprises based on knowledge economy. Fujian Tea, 2018, 40(8).

[3] Chen Xi. An introduction to enterprise management innovation based on the current context. Consumer Guide Journal, 2018(18).

[4] Feng, Liang-Yuan. Briefly discussing the innovation and practice of enterprise economic management based on the knowledge economy. Investment and Cooperation, 2012(11).

\section{Author Profile}

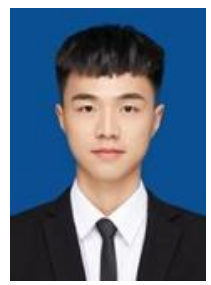

Jingchao Pan received the B.S. and M.S. degrees in Economics from Fujian Normal University Minnan Science and Technology Institute and Belarusian State University in 2020 and 2021. Now he is a $\mathrm{PhD}$ in Universiti Sains Malaysia. 